\title{
Modification of Non-Metallic Inclusions in Stainless Steel by Addition of $\mathrm{CaSi}$
}

\author{
Hongying Du ${ }^{1, * \mathbb{D}}$, Andrey Karasev ${ }^{1}$, Olle Sundqvist ${ }^{2}$ and Pär G. Jönsson ${ }^{1}{ }^{\mathbb{C}}$ \\ 1 KTH Royal Institute of Technology, Brinellvägen 23, Stockholm 10044, Sweden; karasev@kth.se (A.K.); \\ parj@kth.se (P.G.J.) \\ 2 Sandvik Materials Technology AB, Sandviken 81181, Sweden; olle.sundqvist@sandvik.com \\ * Correspondence: hongying@kth.se; Tel.: +46-(0)8-790-8306
}

Received: 10 December 2018; Accepted: 8 January 2019; Published: 12 January 2019

\begin{abstract}
The focus of this study involved comparative investigations of non-metallic inclusions in 316L stainless steel bars without and with Ca treatments. The inclusions were extracted by using electrolytic extraction (EE). After that, the characteristics of the inclusions, such as morphology, size, number, and composition, were investigated by using a scanning electron microscope (SEM) in combination with an energy dispersive X-ray spectroscopy (EDS). The following four types of inclusions were observed in 316L steels: (1) Elongated MnS (Type I), (2) MnS with hard oxide cores (Type II), (3) Undeformed irregular oxides (Type III), and (4) Elongated oxides with a hard oxide core (Type IV). In the reference sample, only a small amount of the Type III oxides $\left(\mathrm{Al}_{2} \mathrm{O}_{3}-\mathrm{MgO}-\mathrm{MnO}-\mathrm{TiO}_{x}\right)$ existed. However, in Ca-treated 316L steel, about $46 \%$ of the observed inclusions were oxide inclusions (Types III and IV) correlated to gehlenite and to a mixture of gehlenite and anorthite, which are favorable for the machinability of steel. Furthermore, untransformed oxide cores $\left(\mathrm{Al}_{2} \mathrm{O}_{3}-\mathrm{MgO}-\mathrm{MnO}\right)$ were also found in the inclusions of Type IV. The mechanism leading to different morphologies of oxide inclusions is also discussed.
\end{abstract}

Keywords: stainless steel; Ca treatment; non-metallic inclusion; electrolytic extraction

\section{Introduction}

Non-metallic inclusions (NMIs) play a detrimental role with respect to the quality and mechanical properties of steels, causing reduced toughness and shorter fatigue life and potentially increasing the failure risk of the final product [1]. The effect of inclusions on the mechanical properties of steels depends on the chemical composition, density, size, shape, orientation, and distribution of the inclusions. One approach applied for decades in the steelmaking industry is to develop steels with low levels of impurities. However, it is also reported that some inclusions (such as MnS and Ca-modified oxides, among others) can help to improve the steel machinability (for instance by decreasing the wear on the cutting tool, thus extending the tool's life) [2]. Previous studies [3-5] show that inclusions improve machinability primarily by two ways: (1) as a source of stress concentration effects, favoring machinability by reducing the cutting force and increasing the chip breakability during machining, (2) as a lubricant (tool protection layer) in the contact zone of the cutting tool and material (reducing the abrasive and chemical wear of the tool), which is beneficial for the tool life. Thus, modification of NMIs and control of their characteristics in steels during steel manufacturing are very important to balance favorable machinability properties with the desired mechanical property for diverse types of steels.

$\mathrm{Ca}$ treatment is one way to modify the inclusions. For instance, $\mathrm{Al}_{2} \mathrm{O}_{3}$ inclusions in aluminum-killed steels, which can form clusters up to more than $100 \mu \mathrm{m}$, can be modified to smaller compact spherical calcium-aluminate $\left(\mathrm{CaO}-\mathrm{Al}_{2} \mathrm{O}_{3}\right)$ inclusions by calcium addition [6,7]. It is also 
reported that the suggested content of $\mathrm{CaO}$ in modified inclusions after modification should be in the range 25-60 wt \% [8]. However, Guo et al. [9] reported that the formation of sulfide enriched by $\mathrm{CaS}$ (with quite a high melting temperature) might cause a nozzle clogging problem during casting of free cutting and structural steels with high sulfur contents. Therefore, it is difficult to control sulfide shape by $\mathrm{Ca}$ addition. Liu et al. [10] found that inclusion compositions changed from $\mathrm{Al}_{2} \mathrm{O}_{3}$ to $\mathrm{CaO}-\mathrm{Al}_{2} \mathrm{O}_{3}-\mathrm{CaS}$ by $\mathrm{Ca}$ treatment of $\mathrm{X70}$ pipeline steel.

The modification of oxide inclusions by $\mathrm{Ca}$ addition can also improve the machinability of steels [11-15]. For instance, Bletton et al. [11] investigated the inclusion types and machinability properties in three samples of AISI 316L stainless steel with different Ca contents taken from hot-rolled bars. They concluded that the anorthite $\left(\mathrm{CaO} \cdot \mathrm{Al}_{2} \mathrm{O}_{3} \cdot 2 \mathrm{SiO}_{2}\right)$ and gehlenite $\left(2 \mathrm{CaO} \cdot \mathrm{Al}_{2} \mathrm{O}_{3} \cdot \mathrm{SiO}_{2}\right)$ inclusions, having relatively low melting temperatures, can be more easily deformed and form a protective lubricant layer between the workpiece and cutting tools during machining. Ånmark et al. [14] investigated the effect of Ca-rich inclusions on tool wear during the hard-turning of a Ca-treated carburizing steel. Ca treatment improved the tool life significantly by the formation of a Ca-enriched slag barrier composed of $(\mathrm{Mn}, \mathrm{Ca}) \mathrm{S}$ and $(\mathrm{Ca}, \mathrm{Al})(\mathrm{O}, \mathrm{S})$ on the tool. However, systematic investigations of inclusion characteristics and their effect on the final properties of Ca-treated industrial stainless steels have not been sufficient up to now.

Conventionally, NMIs in steels are evaluated in two dimensions (2D) on a polished cross section of a metal sample by using light optical (LO) or scanning electron microscope (SEM). Previous research [16-18] has established significant drawbacks of this 2D conventional method and suggested three-dimensional (3D) investigations based on extraction methods for more reliable measurements regarding the number and size of different inclusions and clusters.

This study is focused on comparative investigations of non-metallic inclusions in industrial 316L Si-killed stainless steels without and with Ca treatment. Here, 3D investigations of inclusions on film filters after electrolytic extraction (EE) were conducted for the evaluation of inclusions characteristics (such as morphology, size, number, and composition) in stainless steel without and with Ca treatment.

\section{Materials and Methods}

\subsection{Materials}

Steel samples of industrial 316L stainless steel produced without (reference heat-316R) and with $\mathrm{Ca}$ addition (experimental heat-316Ca) were evaluated in this study. The compositions of steels were determined by the steelmaking company (Sandvik Materials Technology AB, Sandviken, Sweden), using usual standard techniques. Details of their compositions are given in Table 1. It should be noted that the contents of sulfur and oxygen in 316Ca steel were higher than in 316R steel.

Table 1. Composition of samples of the reference steel (316R) and the Ca-treated steel (316Ca).

\begin{tabular}{|c|c|c|c|c|c|c|c|c|c|c|}
\hline \multirow{2}{*}{ Steel Grade } & \multirow{2}{*}{ Ca-treated } & $\mathrm{C}$ & Si & Mn & $\mathrm{Cr}$ & $\mathrm{Ni}$ & $S^{a}$ & $\mathrm{O}^{\mathrm{a}}$ & $\mathrm{Ca}^{\mathrm{a}}$ & $\mathrm{Al}^{\mathrm{a}}$ \\
\hline & & \multicolumn{9}{|c|}{ (mass \%) } \\
\hline $316 \mathrm{R}$ & No & 0.02 & 0.38 & 1.60 & 16.82 & 11.18 & 70 & 20 & - & 40 \\
\hline $316 \mathrm{Ca}$ & Yes & 0.01 & 0.46 & 1.58 & 16.86 & 11.14 & 90 & 59 & 28 & 40 \\
\hline
\end{tabular}

The production route for the reference and experimental heats in the company is shown in Figure 1. It includes scrap melting in an electric arc furnace (EAF), de-carburization in an argon oxygen decarburization (AOD) converter, ladle treatment in a ladle furnace, and continuous casting. Ca treatment is done by adding a CaSi wire at the end of the ladle treatment. A reference sample was produced by using the same process route without Ca treatment. Steel samples for the evaluation of non-metallic inclusions were cut from the middle-radius zone of hot-rolled bars (Ø121 $\mathrm{mm})$ in the longitudinal direction, as shown in Figure 1. 


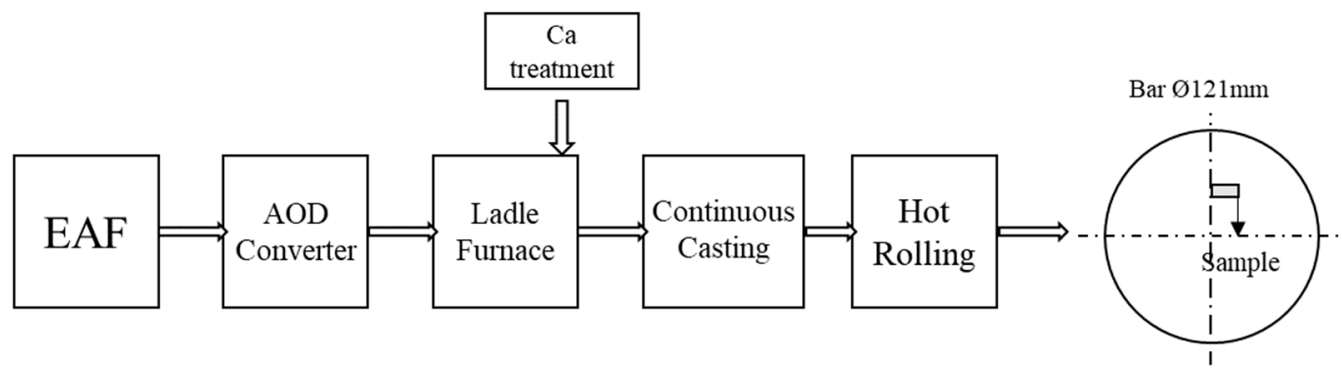

Figure 1. Schematic illustration of the production process of 316L stainless steel, from the melting of scrap and alloys in an Electric Arc Furnace (EAF) to hot rolling.

\subsection{Electrolytic Extraction and Investigation of Inclusions}

For the evaluation of the characteristics of non-metallic inclusions (such as number, size, composition, and morphology), the steel samples were partially dissolved by using EE. However, inclusions did not dissolve during this EE process. Figure 2a shows a schematic diagram of the EE equipment.

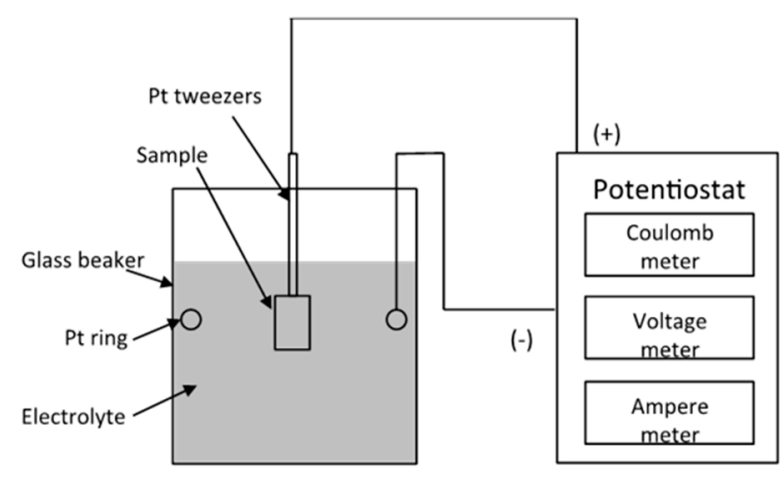

(a)

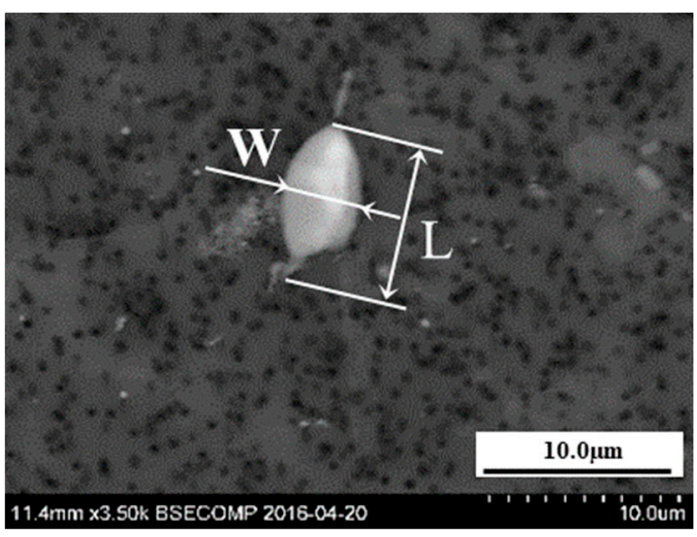

(b)

Figure 2. (a) Schematic diagram of the equipment used for electrolytic extraction (EE); (b) Size measurements of inclusions, where $\mathrm{L}$ and $\mathrm{W}$ are the length and width of the inclusion.

The electrolytic extraction process was carried out by using two different non-aqueous electrolytes, namely $10 \%$ AA (10\% acetylacetone- $1 \%$ tetramethylammonium chloride-methanol) and $2 \%$ TEA ( $2 \%$ triethanolamine- $1 \%$ tetramethylammonium chloride-methanol). The experiments were run with the following electric settings: voltage, 3.2-4.3 V, electric current, $50-70 \mathrm{~mA}$, and electric charge, 500 or 1000 coulombs. The weight of the dissolved metal varied from 0.09 to $0.18 \mathrm{~g}$, depending on the electric charge being used during the extraction.

After extraction, a membrane polycarbonate film filter with an open-pore size of $0.4 \mu \mathrm{m}$ was used to collect the undissolved non-metallic inclusions. The inclusion investigations were performed by using a scanning electron microscope (SEM, S3700N-Hitachi, Hitachi High-Technologies Corporation, Tokyo, Japan) in the back-scattered electrons (BSE) mode at different magnifications. The compositions of the extracted inclusions were analyzed by using energy dispersive X-ray spectroscopy (EDS, Bruker, Karlsruhe, Germany) included in the SEM equipment. The main parameters of the electrolytic extractions and SEM investigations of non-metallic inclusions in different samples are given in Table 2. 
Table 2. Main parameters of the electrolytic extractions and SEM investigations of non-metallic inclusions (NMIs) in different samples.

\begin{tabular}{ccccccc}
\hline Steel Grade & Sample & $\begin{array}{c}\text { Observed Area, } \\
\boldsymbol{A}_{\text {obs }}\left(\mathbf{m m}^{2}\right)\end{array}$ & $\begin{array}{c}\text { Dissolved Metal, } \\
\boldsymbol{W}_{\text {dis }}(\mathbf{g})\end{array}$ & $\begin{array}{c}\text { Dissolved } \\
\text { Depth }(\boldsymbol{\mu m})\end{array}$ & $\begin{array}{c}\text { Number of } \\
\text { Observed NMIs, } \boldsymbol{n}\end{array}$ & $\begin{array}{c}\text { Size Range } \\
(\boldsymbol{\mu m})\end{array}$ \\
\hline $316 \mathrm{R}$ & $\mathrm{R}$ & 0.898 & 0.1563 & $\approx 188$ & 435 & $2-98$ \\
$316 \mathrm{Ca}$ & $\mathrm{A}$ & 0.898 & 0.0935 & $\approx 85$ & 180 & $3-124$ \\
\hline
\end{tabular}

Length $(L)$ and width $(W)$ of different NMIs were measured on the SEM images, as shown in Figure $2 \mathrm{~b}$. The equivalent size $\left(D_{e}\right)$ of deformed elongated inclusion was estimated by using the following equation assuming the inclusion is a long ellipsoid:

$$
D_{e}=\sqrt[3]{W^{2} \cdot L},
$$

The number of inclusions per unit volume of steel $\left(N_{v}\right)$ and volume fraction $\left(f_{v}\right)$ of different NMIs in steel was estimated by using the equations below:

$$
N_{v}=\frac{n}{V_{m}},
$$

where $n$ is the number of observed inclusions, and $V_{m}$ is the volume of dissolved metal that was observed;

$$
f_{v}=\frac{V_{i n c}}{V_{m}}=\frac{\sum_{i=1}^{n}\left(\frac{\pi}{6} \times L_{i} \times W_{i}^{2}\right)}{V_{m}},
$$

where $V_{i n c}$ is the total volume of observed inclusions, $L_{i}$ is the length of the $\mathrm{i}$-th inclusion, and $W_{i}$ is the width of the i-th inclusion.

$$
V_{m}=\frac{w_{d i s}}{\rho} \times \frac{A_{o b s}}{A_{\text {fil }}},
$$

where $A_{f i l}$ is the whole filtration area of a film filter with collected inclusions ( $\left.=1200 \mathrm{~mm}^{3}\right), A_{o b s}$ is the total observed area of the film filter used for the image analysis, $w_{d i s}$ is the weight loss of the metal sample during EE, and $\rho$ is the metal density $\left(=0.0078 \mathrm{~g} / \mathrm{mm}^{3}\right)$.

\section{Results and Discussions}

\subsection{Characterization of Inclusions after Extraction in Different Electrolytes}

It is known that $\mathrm{CaO}$-containing phases in NMIs might be dissolved partially or completely during extraction in strong solutions, otherwise an inaccurate result would be obtained. According to the results reported by Inoue et al. [19], 2\% TEA and 10\% AA electrolytes can be selected for the extraction of $\mathrm{CaO}-\mathrm{Al}_{2} \mathrm{O}_{3}$ and $\mathrm{CaO}-\mathrm{SiO}_{2}$ inclusions depending on the concentration of $\mathrm{CaO}$ in the inclusions. Therefore, both $10 \%$ AA and $2 \%$ TEA electrolytes were used for the extraction of $\mathrm{CaO}-\mathrm{Al}_{2} \mathrm{O}_{3}-\mathrm{SiO}_{2}$ inclusions from Ca-treated 316L steel and comparison of the obtained results in this study.

The contents of $\mathrm{CaO}$ and the ratios of $\mathrm{CaO} / \mathrm{SiO}_{2}$ and $\mathrm{CaO} / \mathrm{Al}_{2} \mathrm{O}_{3}$ in different oxide NMIs extracted by using these two electrolytes are shown in Figure 3, depending on the inclusion length. Dotted lines on this figure correspond to the average values for all analyzed oxide inclusions. 


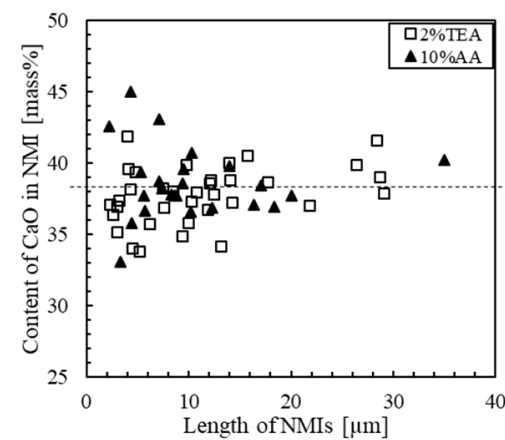

(a)

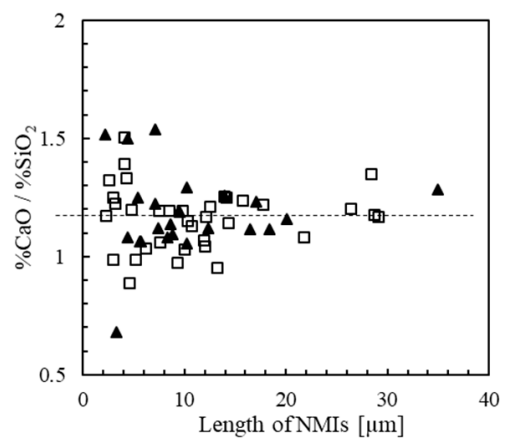

(b)

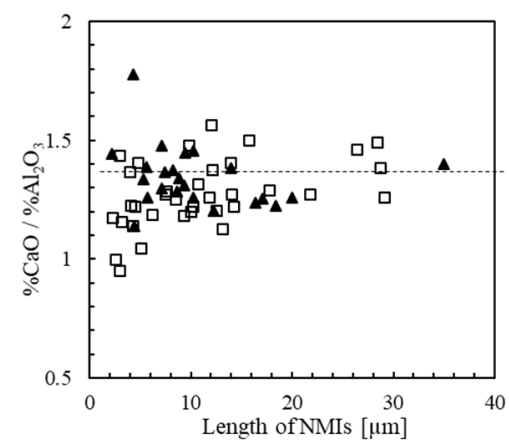

(c)

Figure 3. $\mathrm{CaO}$ contents (a) and ratios of $\% \mathrm{CaO} / \% \mathrm{SiO}_{2}(\mathbf{b})$ and $\% \mathrm{CaO} / \% \mathrm{Al}_{2} \mathrm{O}_{3}$ (c) in oxide inclusions in 316Ca samples after extraction by using $2 \%$ TEA and $10 \%$ AA electrolytes.

It was found that the content of $\mathrm{CaO}$ in all oxide phases of the observed inclusions was lower than $50 \%$. In this case, the compositions of the inclusions extracted by using $2 \%$ TEA and $10 \%$ AA electrolytes did not show differences. Therefore, it may be safely suggested that the $\mathrm{CaO}$-containing phases $(<50 \% \mathrm{CaO})$ in NMIs did not dissolve during both extractions. Moreover, the morphology and size of the observed inclusions after extraction in the two different electrolytes were also similar. On the basis of these results, it was concluded that the $10 \%$ AA electrolyte was suitable to extract $(\mathrm{Ca}, \mathrm{Al}$, $\mathrm{Si}$ ) oxide. Thus, in the remaining document, only the results from using the $10 \%$ AA electrolyte during EE will be discussed.

\subsection{Classification of Non-Metallic Inclusions in $316 R$ and 316Ca Steels}

Overall, four main types of non-metallic inclusions were observed in 316R and 316Ca steels. Typical photos, size ranges, aspect ratios $(\mathrm{AR}=L / W)$, and composition ranges are presented in Table 3 .

Table 3. Classification of the inclusions observed in reference (316R) and Ca-treated (316Ca) stainless steels. AR, aspect ratio.

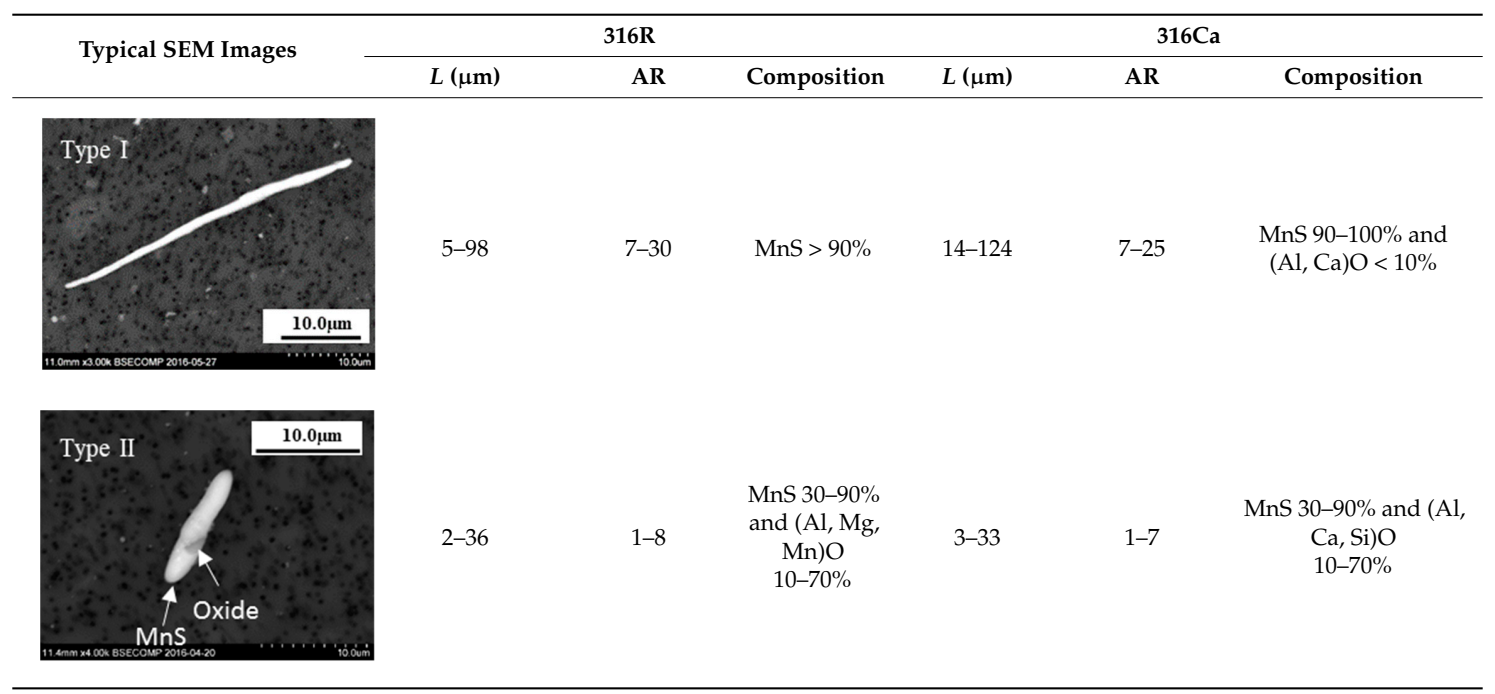


Table 3. Cont

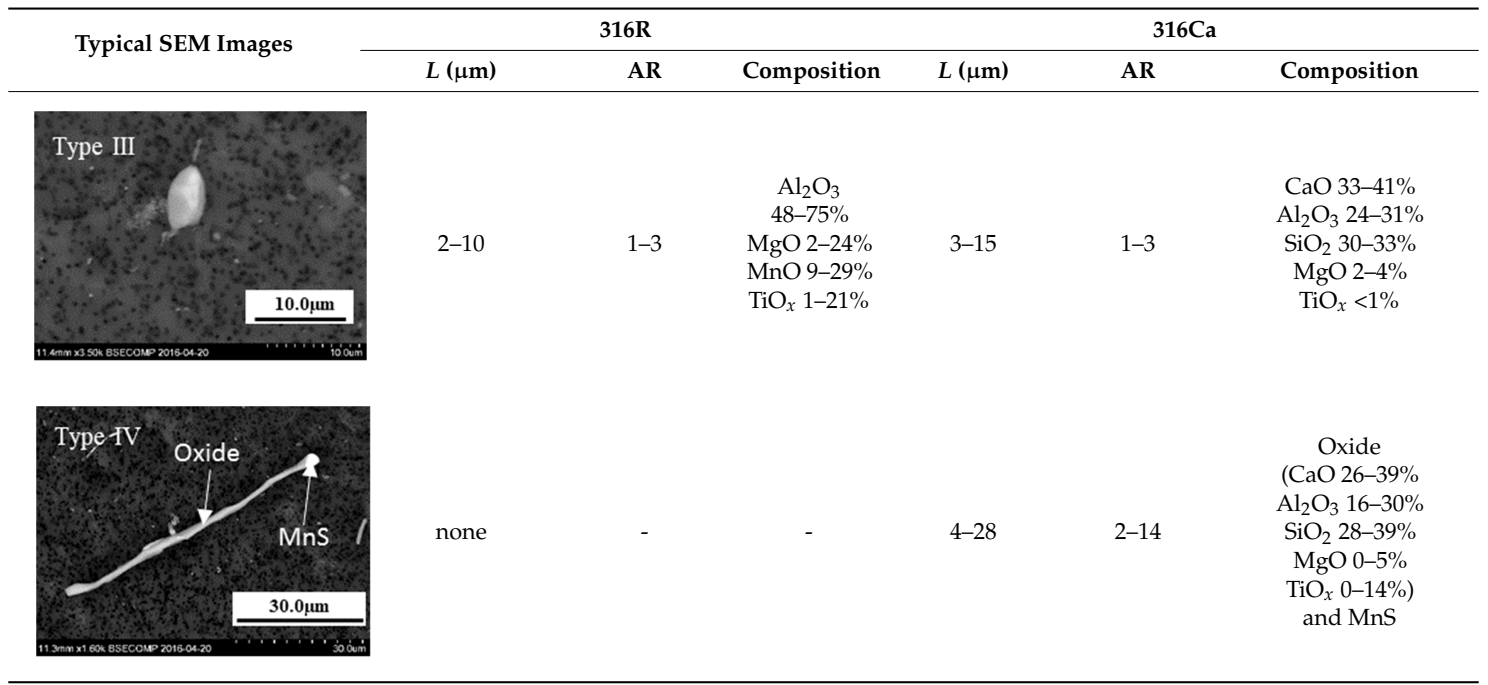

Type I inclusions correspond to elongated rod-like MnS inclusions; Type II inclusions are complex oxy-sulfides, containing a hard oxide core or particles and deformed MnS sulfide; Type III inclusions are undeformable irregular oxides and have quite a homogeneous composition. Type III oxide inclusions in 316R steel contained mostly $\mathrm{Al}_{2} \mathrm{O}_{3}, \mathrm{MgO}, \mathrm{MnO}$, and $\mathrm{TO}_{\mathrm{x}}$, and their size was in the range from 2 up to $10 \mu \mathrm{m}$.

Type III inclusions in the 316Ca steel were mostly undeformable $\mathrm{CaO}-\mathrm{SiO}_{2}-\mathrm{Al}_{2} \mathrm{O}_{3}-\mathrm{MgO}$ oxides. However, some inclusions had a tail containing a higher concentration of $\mathrm{SiO}_{2}$ and lower concentrations of $\mathrm{CaO}$ and $\mathrm{Al}_{2} \mathrm{O}_{3}$. This tail was soft and could be deformed during hot rolling, as shown in Figure $4 \mathrm{a}$.
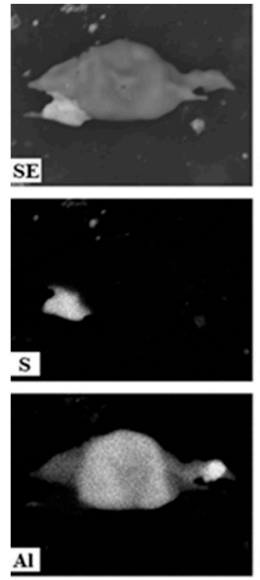
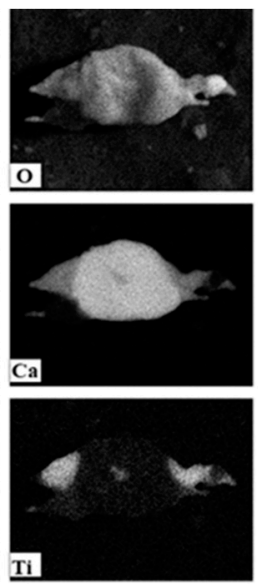

(a)
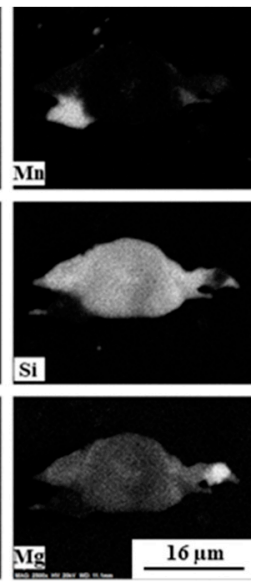

$16 \mu \mathrm{m}$
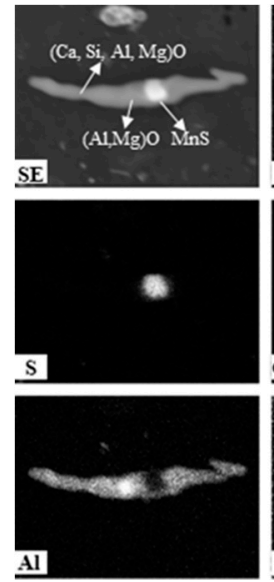

Al
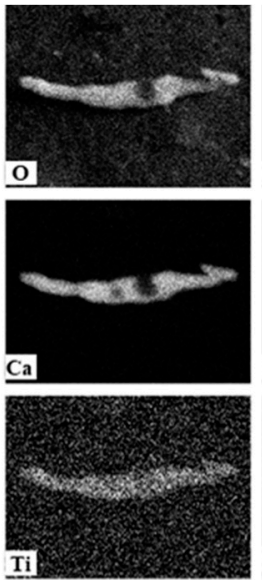

(b)
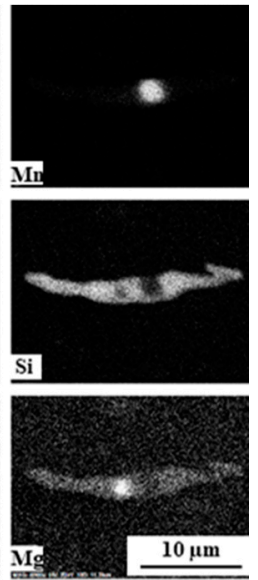

Mg $10 \mu \mathrm{m}$

Figure 4. Element mapping of Type III (a) and Type IV (b) inclusions in Ca-treated steel.

Type IV inclusions in 316R steel were not observed. This was due to all oxide inclusions in the reference sample being $\mathrm{Al}_{2} \mathrm{O}_{3}$ or $\mathrm{Al}_{2} \mathrm{O}_{3}-\mathrm{MnO}-\mathrm{MgO}$ phases, which were not deformed during hot rolling. Type IV inclusions in $316 \mathrm{Ca}$ steel corresponded to elongated $\mathrm{CaO}-\mathrm{SiO}_{2}-\mathrm{Al}_{2} \mathrm{O}_{3}$ oxides containing a higher concentration of $\mathrm{SiO}_{2}$ (up to 39\%) and lower concentrations of $\mathrm{CaO}$ and $\mathrm{Al}_{2} \mathrm{O}_{3}$. Moreover, these deformed oxides contained also some amounts of $\mathrm{TiO}_{x}$ and $\mathrm{MgO}$. However, line scanning and EDS mapping of some Type IV inclusions detected unmodified $\mathrm{Al}_{2} \mathrm{O}_{3}-\mathrm{MgO}$ cores, as shown in Figure $4 \mathrm{~b}$. This can explain the quite high $\mathrm{Al}_{2} \mathrm{O}_{3}$ and $\mathrm{MgO}$ contents in some Type IV inclusions determined during EDS investigation. 
Similar inclusions, having an $\mathrm{Al}_{2} \mathrm{O}_{3}-\mathrm{MgO}$ core covered by a Ca-rich oxide layer, have also been reported by other researchers [20,21]. Furthermore, an undeformed manganese sulfide particle could be found in this inclusion during the investigation. Elongated oxide inclusions containing manganese sulfide cores were also found by Bletton et al. [20]. These deformable lime silicoaluminate inclusions were mainly determined as pseudo-wollastonite, gehlenite, and anorthite $[11,20]$. They were predominantly bound up with sulfides and were found to form associated inclusions containing manganese sulfide cores.

\subsection{Particle Size Distribution of the Inclusions Observed in 316R and 316Ca Steels}

The number of inclusions per unit volume $\left(N_{v}\right)$, size, $A R$, and volume fraction $\left(f_{v}\right)$ of diverse types of inclusions is given in Table 4 .

Table 4. Distribution and information about different types of inclusions found in 316Ca steel.

\begin{tabular}{|c|c|c|c|c|c|c|c|c|}
\hline Samples & $\begin{array}{c}\text { Inclusion } \\
\text { Type }\end{array}$ & $L(\mu \mathrm{m})$ & $W(\mu \mathrm{m})$ & $D_{\mathrm{e}}(\mu \mathrm{m})$ & $\mathrm{AR}$ & $f_{v} \times 10^{4}$ & $\begin{array}{c}N_{v} \\
\left(\mathrm{~mm}^{-3}\right)\end{array}$ & $\begin{array}{c}\text { Frequency } \\
\text { (\%) }\end{array}$ \\
\hline \multirow{4}{*}{$316 R$} & Type I & $\begin{array}{c}33.2 \pm 24.8 \\
(5-98)\end{array}$ & $\begin{array}{c}2.6 \pm 1.4 \\
(1-7)\end{array}$ & $\begin{array}{c}6.0 \pm 3.5 \\
(1-16)\end{array}$ & $7-30$ & 6.7 & 2667 & 9.2 \\
\hline & Type II & $\begin{array}{c}5.0 \pm 3.8 \\
(2-36)\end{array}$ & $\begin{array}{c}1.8 \pm 0.7 \\
(1-7)\end{array}$ & $\begin{array}{c}2.4 \pm 1.1 \\
(1-10)\end{array}$ & $1-8$ & 3.7 & 24,933 & 86.4 \\
\hline & Type III & $\begin{array}{c}5.4 \pm 2.2 \\
(2-10)\end{array}$ & $\begin{array}{c}3.6 \pm 1.5 \\
(2-8)\end{array}$ & $\begin{array}{c}4.0 \pm 1.6 \\
(2-9)\end{array}$ & $1-3$ & 0.7 & 1267 & 4.4 \\
\hline & Type IV & - & - & - & - & & - & - \\
\hline \multirow{4}{*}{$316 \mathrm{Ca}$} & Type I & $\begin{array}{c}43.0 \pm 32.4 \\
(14-124)\end{array}$ & $\begin{array}{c}3.7 \pm 1.1 \\
(2-5)\end{array}$ & $\begin{array}{c}8.1 \pm 3.2 \\
(4-14)\end{array}$ & $7-25$ & 4.1 & 1003 & 5.0 \\
\hline & Type II & $\begin{array}{c}7.0 \pm 4.8 \\
(3-33)\end{array}$ & $\begin{array}{c}2.6 \pm 0.8 \\
(1-5)\end{array}$ & $\begin{array}{c}3.6 \pm 1.3 \\
(2-10)\end{array}$ & $1-7$ & 3.5 & 9811 & 48.9 \\
\hline & Type III & $\begin{array}{c}6.2 \pm 3.0 \\
(3-15)\end{array}$ & $\begin{array}{c}3.3 \pm 0.9 \\
(2-6)\end{array}$ & $\begin{array}{c}4.1 \pm 1.3 \\
(2-8)\end{array}$ & $1-3$ & 2.1 & 4460 & 22.2 \\
\hline & Type IV & $\begin{array}{c}10.7 \pm 5.2 \\
(4-28)\end{array}$ & $\begin{array}{c}2.3 \pm 0.6 \\
(1-4)\end{array}$ & $\begin{array}{c}3.8 \pm 1.1 \\
(2-7)\end{array}$ & $2-14$ & 1.7 & 4794 & 23.9 \\
\hline
\end{tabular}

$D_{\mathrm{e}}$, equivalent size of deformed elongated inclusions; $f_{v}$, volume fraction; $N_{v}$, number of inclusions per unit volume of steel.

It can be seen that the reference 316R sample contained mostly MnS inclusions of Type II (86\%) and Type I (9\%). Only a small amount of Type III oxides $\left(\mathrm{Al}_{2} \mathrm{O}_{3}-\mathrm{MgO}-\mathrm{MnO}-\mathrm{TO}_{x}\right)$ existed in this sample. Also, almost pure $\mathrm{Al}_{2} \mathrm{O}_{3}$ inclusions were found in the sample. However, Type IV inclusions were not observed in the reference sample.

Although the content of $S$ in the Ca-treated steel (316Ca) was higher, the number of elongated sulfides of Type I and oxy-sulfides of Type II was about 2.5 times smaller compared to that in the reference 316R steel. However, the length, width, and equivalent size of those inclusions in 316Ca steel were larger than the respective characteristics of the given inclusions in 316R steel. The number of oxide inclusions in the Ca-treated steel increased significantly and corresponded to $\approx 22 \%$ and $\approx 24 \%$ of the total amount of observed inclusions for Type III and Type IV inclusions, respectively. This can be explained by the higher content of oxygen in 316Ca steel compared to the 316R steel. Overall, Ca treatment of $316 \mathrm{~L}$ stainless steel decreased the total number of inclusions by $\approx 30 \%$, though the total $f_{v}$ of the inclusions were similar in both samples.

The size distributions of different types of inclusions obtained by SEM are shown in Figure 5 in terms of $N_{v}$ with a constant size step of $5 \mu \mathrm{m}$. It can be seen that the oxy-sulfide inclusions of Type II were the most numerous. However, Ca treatment of steel decreased the number of small-size oxy-sulfides $(L<10 \mu \mathrm{m})$ by about three times. 


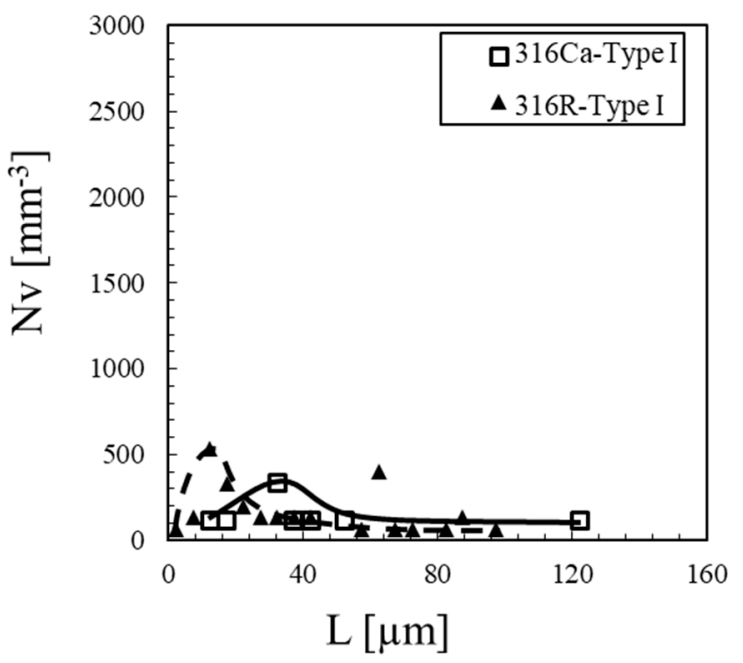

(a)

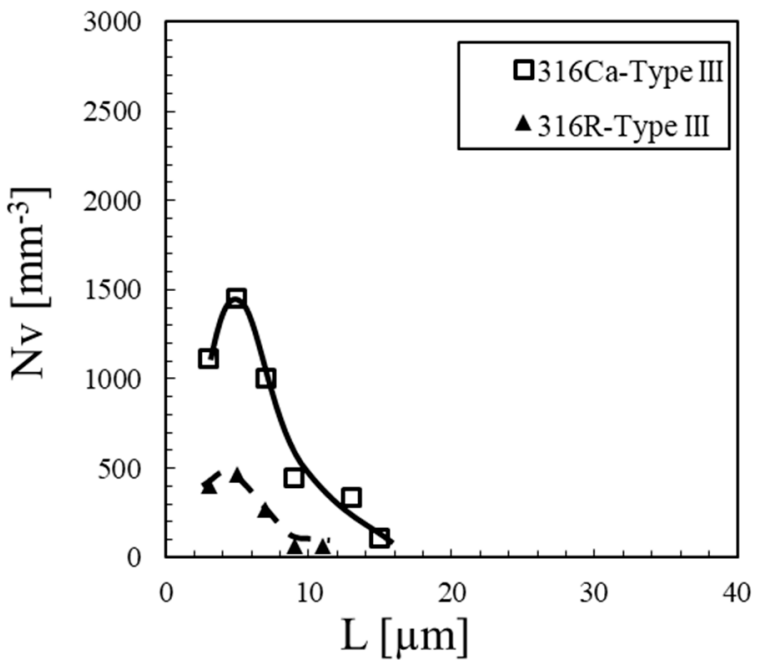

(c)

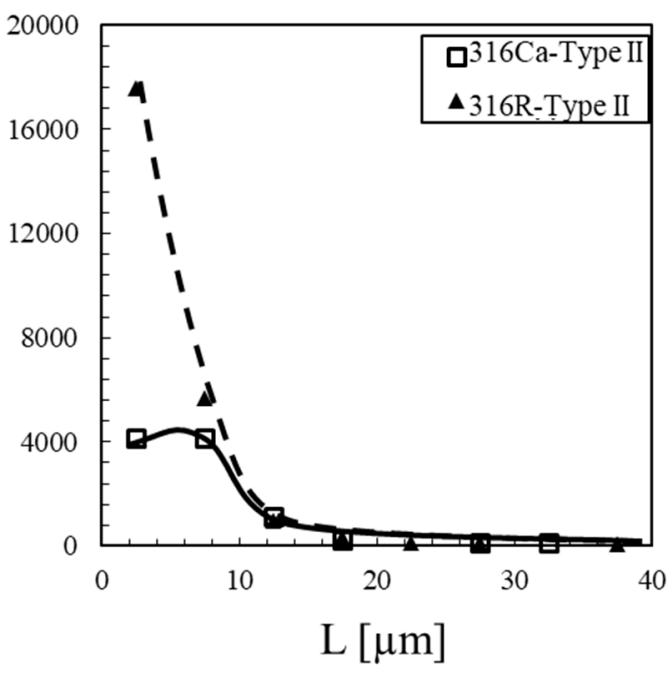

(b)

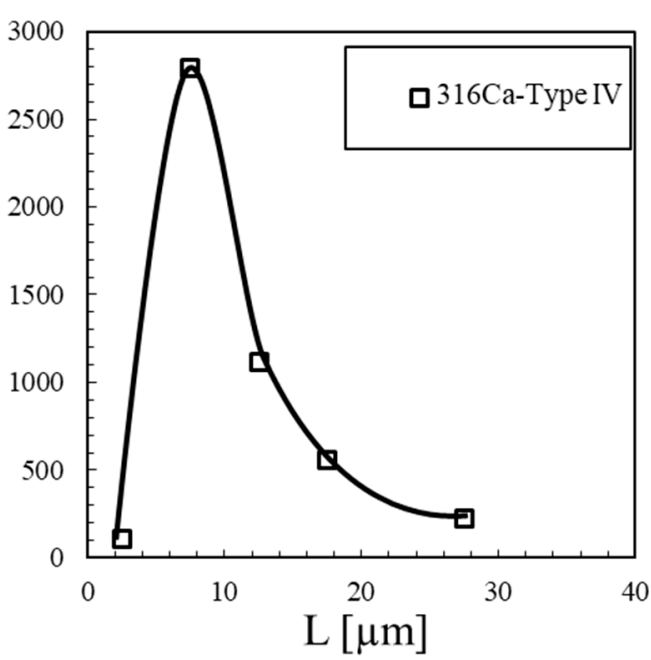

(d)

Figure 5. Particle size distributions of different NMI types observed in the metal samples of $316 \mathrm{R}$ and 316Ca steel bars.

The contents of the main oxide components $\left(\mathrm{Al}_{2} \mathrm{O}_{3}, \mathrm{SiO}_{2}\right.$, and $\left.\mathrm{CaO}\right)$ in the typical Type III and Type IV inclusions in 316Ca steel are shown in Figure 6 as a function of inclusion length. It can be seen that the compositions of large-size Type III oxides $(L>6 \mu \mathrm{m})$ were more stable and homogeneous because the contents of $\mathrm{Al}_{2} \mathrm{O}_{3}, \mathrm{SiO}_{2}$, and $\mathrm{CaO}$ were similar. However, Type IV complex oxides were heterogeneous due to the high scattering of the composition for inclusions of different size. As shown in Figure $4 \mathrm{~b}$, Type IV inclusions contained an untransformed oxide core having very high contents of $\mathrm{Al}_{2} \mathrm{O}_{3}$ and $\mathrm{MgO}$ and small contents of $\mathrm{CaO}$ and $\mathrm{SiO}_{2}$. Furthermore, undeformed $\mathrm{MnS}$ particles were detected in some elongated Type IV inclusions, but $\mathrm{CaS}$ was not found. 


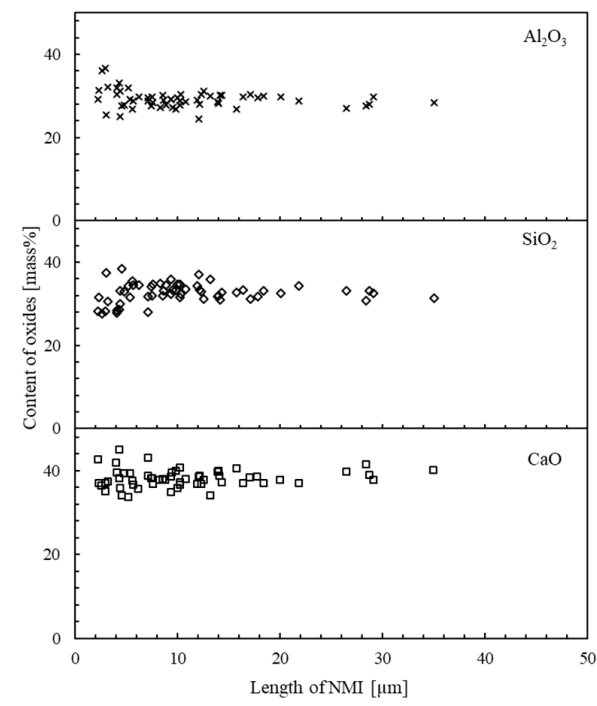

(a)

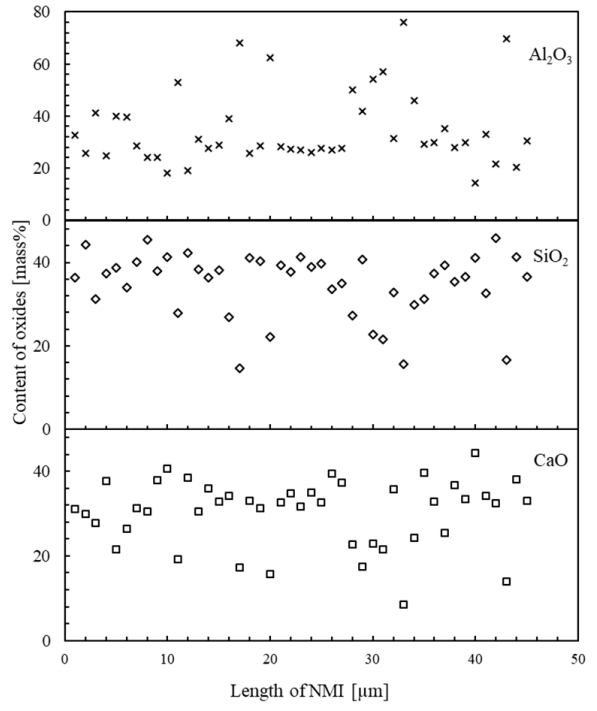

(b)

Figure 6. Relationship between the $\mathrm{Al}_{2} \mathrm{O}_{3}, \mathrm{SiO}_{2}$, and $\mathrm{CaO}$ contents and length of Type III (a) and Type IV (b) oxide inclusions in 316Ca steel.

The triangle $\mathrm{CaO}-\mathrm{Al}_{2} \mathrm{O}_{3}-\mathrm{SiO}_{2}$ diagram in Figure 7 shows that most oxides of Type II (black diamond marks) and Type III (green triangle marks) in 316Ca steel were located in the area near gehlenite with a melting point $\geq 1500{ }^{\circ} \mathrm{C}$. The elongated part of Type IV inclusions had a higher content of $\mathrm{SiO}_{2}$ and was located in the zone between the anorthite $\left(\mathrm{CaO} \cdot \mathrm{Al}_{2} \mathrm{O}_{3} \cdot 2 \mathrm{SiO}_{2}\right)$ and gehlenite $\left(2 \mathrm{CaO} \cdot \mathrm{Al}_{2} \mathrm{O}_{3} \cdot \mathrm{SiO}_{2}\right)$ phases, which corresponds to a lower melting point zone (around $1300-1400{ }^{\circ} \mathrm{C}$ ). This composition of inclusions corresponds to a liquid phase during steel casting and to a soft oxide during rolling. The undeformed oxide core of Type IV inclusions had a similar ratio of $\mathrm{CaO}$ and $\mathrm{SiO}_{2}$ (around 1:1) as the outer layer but a much higher content of $\mathrm{Al}_{2} \mathrm{O}_{3}$ and $\mathrm{MgO}(40 \%-95 \%)$, which corresponded to the oxide phases with higher melting points $\left(>1450^{\circ} \mathrm{C}\right)$. Therefore, it can be concluded that the undeformed cores contained almost pure $\mathrm{Al}_{2} \mathrm{O}_{3}$ or $\mathrm{Al}_{2} \mathrm{O}_{3}-\mathrm{MgO}$.

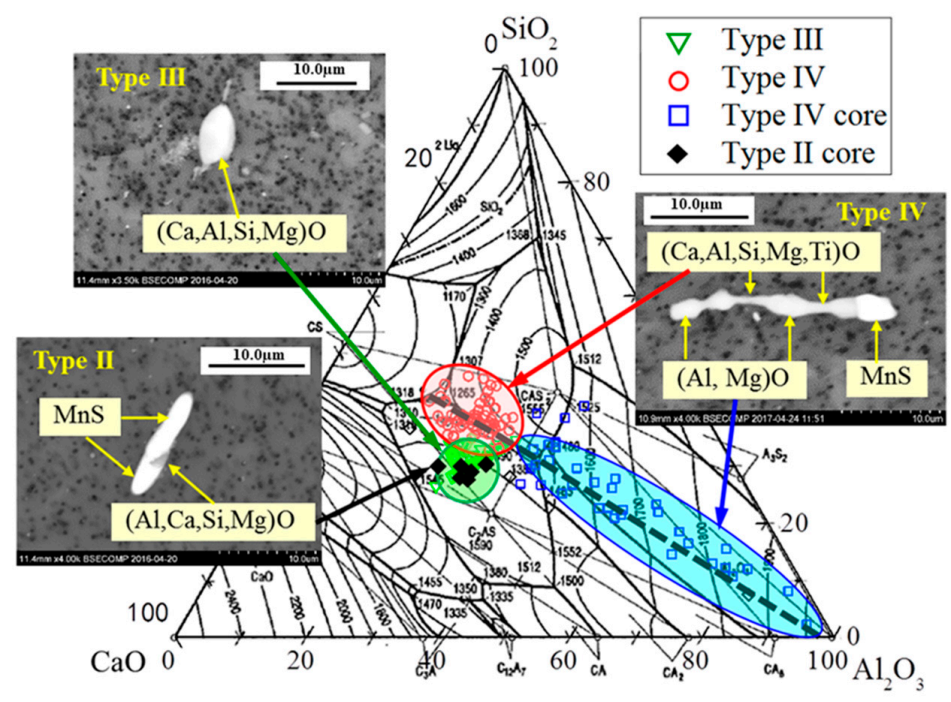

Figure 7. Composition of oxide inclusions in the Ca-treated sample (316Ca) in a $\mathrm{CaO}-\mathrm{Al}_{2} \mathrm{O}_{3}-\mathrm{SiO}_{2}$ ternary phase diagram. 


\subsection{Mechanism of Inclusion Transformation}

On the basis of the obtained results, it was shown that two types of oxide inclusions (Type III and Type IV inclusions) can be formed simultaneously during Ca treatment of 316L stainless steel. The presence of these two types of modified inclusions in steel can be explained by some differences between the initial oxide inclusions before CaSi addition. It was found that Type III oxide inclusions in 316R steel could be divided into two groups: (i) Type IIIa-liquid or semi-liquid inclusions with higher content of $\mathrm{MnO}$ and $\mathrm{TiO}_{x}\left(17-60 \% \mathrm{Al}_{2} \mathrm{O}_{3},<10 \% \mathrm{MgO}, 15-29 \% \mathrm{MnO}\right.$, and 5-21\% $\mathrm{TiO}_{x}$ ) and (ii) Type IIIb-regular/irregular solid oxide inclusions with higher contents of $\mathrm{Al}_{2} \mathrm{O}_{3}$ and $\mathrm{MgO}(60-75 \%$ $\mathrm{Al}_{2} \mathrm{O}_{3}, 10-24 \% \mathrm{MgO}, 9-15 \% \mathrm{MnO}$, and 1-10\% $\mathrm{TiO}_{x}$ ).

After the addition of the $\mathrm{CaSi}$ wire, most of $\mathrm{MnO}$ and $\mathrm{TiO}_{x}$, and part of $\mathrm{Al}_{2} \mathrm{O}_{3}$ in the liquid Type IIIa oxides could be reduced more easily and faster by $\mathrm{Ca}$ and $\mathrm{Si}$. Therefore, $\mathrm{CaO}$ content was larger in the homogeneous Type III oxides in 316Ca steel. As a result, these obtained inclusions were harder and could not be deformed during hot rolling. A small amount of oxide phases, that were precipitated later on the surface of these solid oxides of Type III, had a smaller $\mathrm{CaO}$ content and a larger $\mathrm{SiO}_{2}$ content due to the fast decrease of the Ca concentration in the melt. These precipitated phases were softer and could be deformed during hot rolling (as shown in by the tails in Figure 4a).

Other solid oxides, having a larger concentration of $\mathrm{Al}_{2} \mathrm{O}_{3}$ and $\mathrm{MgO}$ (Type IIIb), could not be modified quickly and completely due to a limitation of reduction reactions in the solid oxide phases. Therefore, an outer layer of modified oxides was formed slower due to the fast decreasing Ca concentration in the melt. As a result, the outer oxide layer had a smaller $\mathrm{CaO}$ content and a larger $\mathrm{SiO}_{2}$ content compared to the solid oxide of Type III and could be deformed during hot rolling (as shown in Figure 4b). However, these Type IV modified complex inclusions in 316Ca steel could have an undeformed core that contained mostly $\mathrm{Al}_{2} \mathrm{O}_{3}$ and $\mathrm{MgO}$.

Thus, after Ca treatment of $316 \mathrm{~L}$ steel, about $46 \%$ of the observed inclusions were oxide inclusions (Types III and IV) correlated to gehlenite and to a mixture of gehlenite and anorthite inclusions. Therefore, it is believed that these modified oxide inclusions (especially the Type IV inclusions) can significantly improve the machinability of 316L stainless steel. The effects of different types of inclusions observed in Ca-treated stainless steel will be discussed in a separate article.

\section{Conclusions}

Non-metallic inclusions in commercial 316L steels without Ca treatment (316R) and with Ca treatment $(316 \mathrm{Ca}$ ) were studied. The characteristics of the inclusions were determined by using $3 \mathrm{D}$ investigations after EE. Based upon the presented experimental results, the following conclusions were drawn:

1. Similar compositions of oxide inclusions in 316Ca steel were obtained after EE by using $2 \%$ TEA and $10 \%$ AA electrolytes.

2. The 316L steels contained four types of inclusions: (1) elongated MnS (Type I), (2) MnS sulfides with hard oxide cores (Type II), (3) undeformed irregular oxides (Type III), and (4) elongated oxides with a hard oxide core (Type IV).

3. In the reference sample, the oxide composition was mainly $\mathrm{Al}_{2} \mathrm{O}_{3}-\mathrm{MgO}-\mathrm{MnO}$. However, after Ca treatment of 316L steel, about $46 \%$ of the observed inclusions were oxide inclusions (Types III and IV), which correlated to gehlenite and to a mixture of gehlenite and anorthite, which are favorable for the machinability of steel.

Author Contributions: Conceptualization, A.K., O.S., and P.G.J.; formal analysis, H.D., material preparation, O.S.; investigation, H.D.; writing—original draft preparation, H.D.; writing—review and editing, A.K, O.S., and P.G.J.; supervision, A.K. and P.G.J.

Funding: This research received no external funding

Acknowledgments: The VINNOVA, Jernkontoret are acknowledged for the support of this study. H. Du acknowledges the financial support from the China Scholarship Council (CSC). 
Conflicts of Interest: The authors declare no conflict of interest.

\section{References}

1. Cyril, N.; Fatemi, A.; Cryderman, B. Effects of sulfur level and anisotropy of sulfide inclusions on tensile, impact, and fatigue properties of SAE 4140 steel. SAE Int. J. Manuf. Mater. 2008, 1, 218-227. [CrossRef]

2. Ånmark, N.; Karasev, A.; Jönsson, P.G. The Influence of Microstructure and Non-Metallic Inclusions on the Machinability of Clean Steels. Steel Res. Int. 2016, 87, 1-8. [CrossRef]

3. Wang, Y.; Yang, J.; Bao, Y. Effects of Non-metallic Inclusions on Machinability of Free-Cutting Steels Investigated by Nano-Indentation Measurements. Metall. Mater. Trans. A 2015, 46, 281-292. [CrossRef]

4. Qi, H.S.; Mills, B. On the formation mechanism of adherent layers on a cutting tool. Wear 1996, 198, $192-196$. [CrossRef]

5. Sidjanin, L.; Kovac, P. Fracture mechanisms in chip formation processes. Mater. Sci. Technol. 1997, 13, $439-444$. [CrossRef]

6. Abdelaziz, S.; Megahed, G.; El-Mahallawi, I.; Ahmed, H. Control of Ca addition for improved cleanness of low C, Al killed steel. Ironmak Steelmak 2009, 36, 432-441. [CrossRef]

7. Verma, N.; Pistorius, P.C.; Fruehan, R.J.; Potter, M.; Lind, M.; Story, S. Transient Inclusion Evolution During Modification of Alumina Inclusions by Calcium in Liquid Steel: Part II. Results and Discussion. Metall. Mater. Trans. B 2011, 42, 720-729. [CrossRef]

8. Lis, T. Modification of oxygen and sulphur inclusions in steel by calcium treatment. Metalurgija 2009, 48, 95-98.

9. Guo, Y.; He, S.; Chen, G.; Wang, Q. Thermodynamics of Complex Sulfide Inclusion Formation in Ca-Treated Al-Killed Structural Steel. Metall. Mater. Trans. B 2016, 47, 2549-2557. [CrossRef]

10. Liu, J.; Wu, H.; Bao, Y.; Wang, M. Inclusion variations and calcium treatment optimization in pipeline steel production. Int. J. Miner. Metall. Mater. 2011, 18, 527. [CrossRef]

11. Bletton, O.; Duet, R.; Pedarre, P. Influence of oxide nature on the machinability of 316L stainless steels. Wear 1990, 139, 179-193. [CrossRef]

12. Nordgren, A.; Melander, A. Tool wear and inclusion behaviour during turning of a calcium-treated quenched and tempered steel using coated cemented carbide tools. Wear 1990, 139, 209-223. [CrossRef]

13. Fang, X.D.; Zhang, D. An investigation of adhering layer formation during tool wear progression in turning of free-cutting stainless steel. Wear 1996, 197, 169-178. [CrossRef]

14. Ånmark, N.; Björk, T. Effects of the composition of Ca-rich inclusions on tool wear mechanisms during the hard-turning of steels for transmission components. Wear 2016, 368, 173-182. [CrossRef]

15. Gutnichenko, O.; Bushlya, V.; Zhou, J.M.; Stahl, J.E. Tool wear and machining dynamics when turning high chromium white cast iron with pcBN tools. Wear 2017, 390-391, 253-269. [CrossRef]

16. Kanbe, Y.; Karasev, A.; Todoroki, H.; Jönsson, P.G. Application of Extreme Value Analysis for Two- and Three-Dimensional Determinations of the Largest Inclusion in Metal Samples. ISIJ Int. 2011, 51, 593-602. [CrossRef]

17. Karasev, A.; Suito, H. Analysis of size distributions of primary oxide inclusions in Fe-10 mass Pct Ni-M (M = $\mathrm{Si}, \mathrm{Ti}, \mathrm{Al}, \mathrm{Zr}$, and Ce) alloy. Metall. Mater. Trans. B 1999, 30, 259-270. [CrossRef]

18. Kanbe, Y.; Karasev, A.; Todoroki, H.; Jönsson, P.G. Analysis of Largest Sulfide Inclusions in Low Carbon Steel by Using Statistics of Extreme Values. Steel Res. Int. 2011, 82, 313-322. [CrossRef]

19. Inoue, R.; Kiyokawa, K.; Tomoda, K.; Ueda, S.; Ariyama, T. Three-dimensional estimation of multi-component inclusion particles in steel. In Proceedings of the 8th International Workshop on Progress in Analytical Chemistry and Materials Characterisation in the Steel and Metal Industries (CETAS'11), Luxembourg, 17-19 May 2011.

20. Bletton, O.; Duet, R.; Henry, M.; Cogne, J.Y. Resulphurized Austenitic Stainless Steel with Improved Machinability. U.S. Patent 5,089,224, 18 February 1992.

21. Todoroki, H.; Mizuno, K. Effect of Silica in Slag on Inclusion Compositions in 304 Stainless Steel Deoxidized with Aluminum. ISIJ Int. 2004, 44, 1350-1357. [CrossRef]

(C) 2019 by the authors. Licensee MDPI, Basel, Switzerland. This article is an open access article distributed under the terms and conditions of the Creative Commons Attribution (CC BY) license (http:// creativecommons.org/licenses/by/4.0/). 